\title{
Phloem Cytochemical Modification and Gene Expression Following the Recovery of Apple Plants from Apple Proliferation Disease
}

\author{
R. Musetti, A. Paolacci, M. Ciaffi, O. A. Tanzarella, R. Polizzotto, \\ F. Tubaro, M. Mizzau, P. Ermacora, M. Badiani, and R. Osler
}

First, fifth, eighth, and tenth authors: Dipartimento di Biologia e Protezione delle Piante, Università di Udine, via delle Scienze, 208 I-33100 Udine Italy; second, third, and fourth authors: Dipartimento di Agrobiologia e Agrochimica, Università della Tuscia, Via S. Camillo de Lellis snc, I-01100 Viterbo Italy; sixth and seventh authors: Dipartimento di Scienze e Tecnologie Chimiche, Università di Udine, via Cotonificio 108, I-33100 Udine Italy; and ninth author: Dipartimento di Biotecnologie per il Monitoraggio Agro-Alimentare ed Ambientale, Università Meditterranea di Reggio Calabria, Contrada Melissari, I-89124 Reggio Calabria Italy. Accepted for publication 17 December 2009.

\begin{abstract}
Musetti, R., Paolacci, A., Ciaffi, M., Tanzarella, O. A., Polizzotto, R., Tubaro, F., Mizzau, M., Ermacora, P., Badiani, M., and Osler, R. 2010. Phloem cytochemical modification and gene expression following the recovery of apple plants from apple proliferation disease. Phytopathology 100:390-399.

Recovery of apple trees from apple proliferation was studied by combining ultrastructural, cytochemical, and gene expression analyses to possibly reveal changes linked to recovery-associated resistance. When compared with either healthy or visibly diseased plants, recovered apple trees showed abnormal callose and phloem-protein accumulation in their leaf phloem. Although cytochemical localization detected $\mathrm{Ca}^{2+}$ ions in the

phloem proteins were analyzed by quantitative real-time reverse transcription-polymerase chain reaction. In comparison to both healthy and diseased plants, four of the above nine genes were remarkably upregulated in recovered trees. As in infected apple trees, phytoplasma disappear from the crown during winter, but persist in the roots, and it is suggested that callose synthesis/deposition and phloem-protein plugging of the sieve tubes would form physical barriers preventing the recolonization of the crown during the following spring. Since callose deposition and phloem-protein aggregation are both $\mathrm{Ca}^{2+}$-dependent processes, the present results suggest that an inward flux of $\mathrm{Ca}^{2+}$ across the phloem plasma membrane could act as a signal for activating defense reactions leading to recovery in phytoplasma-infected apple trees.
\end{abstract} phloem of all the three plant groups, $\mathrm{Ca}^{2+}$ concentration was remarkably higher in the phloem cytosol of recovered trees. The expression patterns of five genes encoding callose synthase and of four genes encoding
Additional keywords: calcium signaling, Malus domestica.
Apple proliferation (AP) is one of the most economically important plant diseases in Europe, requiring quarantine safeguard. 'Candidatus Phytoplasma mali' (' $\mathrm{Ca}$. P. mali') is the disease agent associated with AP; it is a phloem-restricted and wall-less prokaryote, unculturable in vitro and belongs to the class of Mollicutes (21).

Most cultivars of apple (Malus domestica Borkh), which is the main host of ' $C a$. P. mali', appear to be susceptible, as well as do wild and ornamental plants of the genus Malus. Witches' broom is the most typical symptom of AP and is associated with small and/or bronze reddish leaves, enlarged stipules, leaf-rosette formations, virescent flowers with abnormal number of petals, and low fruit quality (34), which causes significant economic losses.

The spontaneous remission from disease symptoms in apple plants affected by AP is denoted as recovery, which can be permanent under certain circumstances (38). The persistence of symptom remission is affected by the host genotype and by the environment. The recovery potential is related to the colonization

\section{Corresponding author: R. Musetti; E-mail address: Rita.Musetti@uniud.it}

* The $\boldsymbol{e}$-Xtra logo stands for "electronic extra" and indicates that the online version contains two articles showing the identification and characterization of cDNAs coding for callose synthases and phloem proteins in apple, a table listing the primer pairs used in qRT-PCR analyses and characteristics of the corresponding amplicons, and two figures showing the relative quantification by qRT-PCR of the expression levels of four or five genes coding for phloem proteins or callose synthase.

doi:10.1094/PHYTO-100-4-0390

(C) 2010 The American Phytopathological Society behavior of phytoplasmas in AP-infected plants. During winter, ' $C a$. P. mali' is eliminated from the above-ground parts of the tree, due to the degeneration of the sieve tubes in the previous year's phloem (44). In spring, the upper parts of the plant can be recolonized starting from the roots, where the phytoplasma persists throughout the year. In recovered trees, phytoplasmas are no longer able to recolonize the crown, although they persist viable and infectious in the roots (8). What causes recovery is not currently known and its physiological bases are poorly understood. When recovered plants are exposed to a high pressure of disease in the field, the probability of developing symptoms is four times lower if compared with never infected trees (38), which suggests the establishment of a type of induced resistance in the latter.

The intervention of phloem sap proteins, plugging affected sieve elements (SE) and thus avoiding microbe penetration/ diffusion and/or loss of nutrients, is a quick and straightforward response in plants undergoing pathogen attack. Phloem protein 1 (PP1) and phloem lectin or phloem protein 2 (PP2), belonging to a well-known class of SE proteins involved in the plugging of sieve pores, were first described in cucurbit phloem sap (42), but are likely present in all dicots. Under oxidative conditions, PP1 monomers and PP2 dimers are covalently cross-linked via disulphide bonds, forming high molecular weight polymers that occlude the sieve pores (42). Such response is normally accompanied by the activation of callose synthase, synthesizing $\beta-1,3-$ glucan which accumulates on sieve plates as plugs, drops, or plates in close proximity to the invading pathogen (10). The SE closure by protein plugs is a fast and reversible mechanism, 
whereas callose deposition is responsible for long-term and permanent plugging of sieve plates $(45,46)$.

As for many other defense responses in plants, including the oxidative burst and the establishment of systemic acquired resistance (29), physical limitation of pathogen spread into the phloem is mediated by the increase of calcium $\left(\mathrm{Ca}^{2+}\right)$ concentration inside SE (13). Lherminier et al. (30) observed that elicitor treatments in phytoplasma-infected tobacco plants increased cytosolic calcium concentration $\left(\left[\mathrm{Ca}^{2+}\right]_{\text {cyt }}\right)$ in the phloem of the elicited plants, followed by the formation of phloem-protein plugs in the lumen of the sieve tubes and occlusion of pore sites by massive callose deposition, hampering the movement of the pathogen all the way through the veins of young leaves. Plantphytoplasma relationships at the gene expression level have been studied in a limited number of species, such as Catharanthus roseus L. (23), Prunus armeniaca (7), Euphorbia pulcherrima (37), and grapevine $(3,20)$ but never in apple plants.

We concentrated on the detection of abnormal callose accumulation and phloem-protein plugging, on the cytochemical localization of $\mathrm{Ca}^{2+}$ ion and its quantification in the cytosolic cell fraction, and on the isolation and expression analysis of genes involved in callose and phloem-protein synthesis. Here, in particular, changes in the apple leaf phloem tissue related to recovery-induced resistance were studied by combining ultrastructural, cytochemical, and gene expression analyses.

\section{MATERIALS AND METHODS}

Plant material and phytoplasma detection. An experimental organic apple orchard (cv. Florina, virus-free clone) was established in 1988 in an area of the Friuli Venezia Giulia region, North East Italy, where serious epidemics of AP occur. The orchard had been checked at least three times per year for the presence of AP symptoms.

Three groups of five plants, symptomatic (diseased, D), healthy $(\mathrm{H})$, and recovered $(\mathrm{R})$, were selected in the orchard. Recovered plants resulted asymptomatic during the previous four consecutive years and healthy plants had been asymptomatic since planting. Leaf samples for all the analyses were collected in September, when typical AP symptoms become evident.

Phytoplasma detection in randomly sampled leaves was carried out by means of polymerase chain reaction (PCR) (31). A phytoplasma DNA enrichment procedure (1) was used to extract DNA from $1 \mathrm{~g}$ of fresh leaf material; PCR was performed using ribosomal fO1/rO1 AP group-specific primers (fO1: CGG AAA CTT TTA GTT TCA GT; rO1: AAG TGC CCA ACT AAA TGA T) (31). Amplification conditions were 35 cycles each at $95^{\circ} \mathrm{C}$ for $30 \mathrm{~s}$, at $55^{\circ} \mathrm{C}$ for $75 \mathrm{~s}$, and at $72^{\circ} \mathrm{C}$ for $90 \mathrm{~s}$. Amplification products were analyzed by direct agarose gel electrophoresis.

Transmission electron microscopy. Pieces of leaf tissue were excised, cut into small portions and fixed for $2 \mathrm{~h}$ at $4{ }^{\circ} \mathrm{C}$ in $0.1 \%$ (wt/vol) buffered sodium phosphate and 3\% (wt/vol) glutaraldehyde at $\mathrm{pH}$ 7.2. They were then postfixed with $1 \%$ osmium tetroxide (wt/vol) in the same buffer for $2 \mathrm{~h}$, dehydrated in an ethanol series, and embedded in Epon/Araldite epoxy resin (Electron Microscopy Sciences, Fort Washington, PA). Several serial ultrathin sections of at least 100 samples from each of the three plant groups were collected on copper grids, stained in uranyl acetate and lead citrate, and then observed under a Philips CM 10 (Eindhoven, The Netherlands) transmission electron microscopy (TEM) operating at $80 \mathrm{kV}$.

Calcium cytolocalization in leaf tissues. Potassium pyroantimonate (KPA) was used as a cytochemical agent for the localization of $\mathrm{Ca}^{2+}$ ions (18). Immediately before its use, potassium hexahydroxyantimonate $\left[\mathrm{KSb}(\mathrm{OH})_{6}\right]$ was solubilized in $0.1 \mathrm{M}$ potassium phosphate buffer, $\mathrm{pH}$ 6.9, containing 3\% (wt/liter) glutaraldehyde, to give a final concentration of $2 \%$ (wt/vol). Leaf samples were fixed in this solution for $2 \mathrm{~h}$ at $4^{\circ} \mathrm{C}$, rinsed in buffer, postfixed in $1 \%$ (wt/liter) osmium tetroxide in $0.1 \mathrm{M}$ potassium phosphate for $1 \mathrm{~h}$ at $4^{\circ} \mathrm{C}$, dehydrated in ethanol, and finally embedded in Epon-Araldite. Ultrathin sections, collected on copper grids, were stained and observed by TEM as specified above.

Quantification of $\left[\mathrm{Ca}^{2+}\right]_{\mathrm{cyt}}$ in apple leaves. Extraction of leaf cytosolic fraction. Leaf midribs ( $1 \mathrm{~g}$ ) were shock-frozen in liquid nitrogen in a sterile mortar and homogenized in $1.5 \mathrm{ml}$ of cold phosphate-buffered saline. Each leaf extract was centrifuged twice at $6,000 \mathrm{rpm}(4,300 \mathrm{~g})$ for $5 \mathrm{~min}$ and the cytosolic fraction was finally collected as the supernatant.

Digestion. To each cytosolic fraction $(0.5 \mathrm{ml}), 1 \mathrm{ml}$ of $65 \%$ (vol/vol) nitric acid, $0.25 \mathrm{ml} \mathrm{30 \%} \mathrm{(vol/vol)} \mathrm{hydrogen} \mathrm{peroxide,}$ and $0.05 \mathrm{ml}$ of fluoridric acid (HF) were added. Then mineralization was carried out in a model 1200 Milestone microwave digestor (FKV, Torre Boldone, Italy), by increasing the electrical power from 250 to $700 \mathrm{~W}$ in $25 \mathrm{~min}$. Samples were then diluted with ultrapure water to a final volume of $100 \mathrm{ml}$ for inductively coupled plasme (ICP) analysis.

ICP-mass spectrometry $(M S)$ analysis. Stock standard solutions for $\mathrm{Ca}^{2+}$ analysis were obtained by diluting as required the corresponding $1,000 \mathrm{mg}$ liter $^{-1}$ of standard solution for ICP (Merck, Darmstadt, Germany) with ultra-pure water (Elgastat UHQ-PS System, Elga Process Water, Marlow, UK), added in all cases with $0.5 \%$ (vol/vol) ultrapure-grade $65 \% \mathrm{HNO}_{3}$ (Merck Suprapur). Both water and nitric acid were previously checked by ICP-MS to ensure that these solutions did not contain more than $0.5 \mu \mathrm{g}$ liter $^{-1}$ of the elements being measured. Final concentrations for calcium were $0,100,1,000,10,000$ and 100,000 $\mu \mathrm{g} \mathrm{liter}^{-1}$, for copper $0,100,1,000$, and $10,000 \mu \mathrm{g} \mathrm{liter}^{-1}$. A solution of $100 \mu \mathrm{g}$ liter $^{-1}$ of rhodium was used as an internal standard. All samples were diluted five times with ultra-pure water to achieve volumes suitable for ICP-MS analysis.

All ICP-MS analyses were carried out with a Spectromass 2000 Type MSDIA10B (Spectro Analytical Instruments, Kieve, Germany). The working frequency was $27.12 \mathrm{MHz}$, with an rf power of 1,350 W. All measurements were performed after calibrating the gas flows, the plasma position with respect to the interface and the ion-optical parameters to maximize the signal with respect to the background noise for both analytes investigated. All analytical data were collected under standard laboratory conditions, i.e., not in a clean-room environment. Calcium isotope 43 was used. Results were the mean of 10 determinations.

Statistics. Quantification of $\left[\mathrm{Ca}^{2+}\right]_{\text {cyt }}$ was carried out in triplicate on leaf material homogeneous in size and symptoms. Statistical analysis was carried out using the Systat version 8.0 software package (SPSS Inc., Chicago, IL) using a one-way analysis of variance followed by the Tukey test to evaluate differences significant. Different letters denote significant differences at $P \leq 0.05$.

Identification of apple genes coding for callose synthase and phloem protein. Several apple cDNAs from transcripts of genes coding for callose synthase (1,3- $\beta$-D-glucan-UDP glucosyltransferase, EC 2.4.1.34) and phloem-proteins were identified by a cross search in the public databases GDR (Genome Database for Rosaceae) (25) and TIGR (40). Twelve nonredundant sequences were identified, and the corresponding tentative consensus sequences from the TIGR apple gene index database were used as templates to design specific primers able to isolate the longest possible transcripts, which included either part of (callose synthases) or the whole coding region (phloem proteins) and their $3^{\prime}$ untranslated region.

RNA isolation from apple leaves. Total RNA was extracted from frozen tissues using a cetylmethyl ammonium bromidebased method described by Gasic et al. (14). The extracted RNA was treated with RNase-free DNase I (Promega Italia, Milano, Italy) according to the manufacturer's protocol. Following digestion, nucleotides were removed from RNA using a G50 Sepharose buffer exchange column (GE Healthcare Europe, Milano, Italy). 
RNA concentration and integrity were checked with a Lambda 3B spectrophotometer (Perkin Elmer Italy, Cologno Monzese, Italy) before and after DNase I digestion. Only RNA samples with a 260/280 ratio (an index of protein contamination) between 1.9 and 2.1 and a 260/230 ratio (an index of reagent contamination) greater than 2.0 before and after DNase I digestion were used for cDNA synthesis. The quality of RNA samples was also assessed by electrophoresis on $1 \%$ formaldehyde agarose gels.

cDNA synthesis, cloning, and sequencing. The transcripts of the 12 identified genes were amplified by RT-PCR using a pool of RNAs extracted from $\mathrm{D}, \mathrm{H}$, and $\mathrm{R}$ leaves as described above. First-strand cDNA was synthesized from $3 \mu \mathrm{g}$ of total RNA by Expand Reverse Transcriptase (Roche Diagnostics, Milano, Italy) according to the manufacturer's protocol.

PCRs were performed by the Expand Long Template PCR System (Roche) according to the manufacturer's protocol using $3 \mu \mathrm{l}$ of RT reaction. After initial denaturation at $94^{\circ} \mathrm{C}$ for $2 \mathrm{~min}$, amplification conditions were 35 cycles each at $94^{\circ} \mathrm{C}$ for $30 \mathrm{~s}$, 58 to $62^{\circ} \mathrm{C}$ (depending on the primer) for $1 \mathrm{~min}$, and $68^{\circ} \mathrm{C}$ for $5 \mathrm{~min}$, followed by a final extension step at $68^{\circ} \mathrm{C}$ for $7 \mathrm{~min}$.

cDNA products were separated on $1.5 \%$ agarose gel, purified by the Sephaglas BandPrep kit (GE Healthcare), and cloned into the modified EcoRV site of pGEM-T plasmid vector (Promega). Plasmid DNA for sequencing reaction was prepared from $3 \mathrm{ml}$ overnight cultures using a plasmid mini-prep kit (Qiagen). Both strands of each cloned cDNA fragments were sequenced by an ABI PRISM 377 capillary sequencer (PE Applied Biosystems Italia, Monza, Italy) using an ABI Prism Dye Terminator sequencing kit (PE Applied Biosystem) and either vector or sequence specific primers.

Gene expression analysis. The expression of the cloned cDNAs were analyzed by quantitative real-time reverse transcription-PCR (qRT-PCR) in leaves from three individual trees for each of the $\mathrm{D}, \mathrm{H}$, and $\mathrm{R}$ groups, collected in September during two consecutive years (2007 to 2008). RT of total RNA was carried out as described above and the resulting cDNA was diluted 1/5 for qRT-PCR analyses. Specific primer pairs were designed for the cloned cDNAs and for the chosen reference genes (Results) using the Beacon Designer 6 software (Stratagene, La Jolla, CA) and imposing the following stringency criteria: $\mathrm{T}_{\mathrm{M}}$ of $55^{\circ} \mathrm{C} \pm 2^{\circ} \mathrm{C}$, PCR amplicon length between 60 and $280 \mathrm{bp}$, primer length of $20 \pm 2 \mathrm{nt}$, and 40 to $60 \%$ guaninecytosine content. Primers were also designed at the $3^{\prime}$ end region of each sequence to encompass all potential splice variants and to ensure equal RT efficiencies.

qRT-PCR analysis was performed using an Mx3000PTM realtime PCR system with Brilliant SYBR green QPCR master mix (Stratagene) according to manufacturer's protocols. qRT-PCR assays were carried out in $25 \mu \mathrm{l}$ reaction volumes containing $1 \mu \mathrm{l}$ of each diluted (1/5) cDNA and $150 \mathrm{nM}$ forward and reverse primers. No template, as well as RT-minus controls, was run to detect contamination, dimer formation and presence of genomic DNA. Five-point standard curves of a fivefold dilution series (1:11:625) from pooled cDNA were used for PCR efficiency calculation of each primer pair. PCR efficiency (E) is given by the equation $E=\left(10^{[-1 / \mathrm{m}]}-1\right) \times 100(41)$, where $\mathrm{m}$ is the slope of linear regression model fitted over log-transformed data of the input cDNA concentration versus $\mathrm{Ct}$ values according to the linear equation $\mathrm{y}=\mathrm{m} \times \log (\mathrm{x})+\mathrm{b}$. The thermal profile comprised three segments: (i) $95^{\circ} \mathrm{C}$ for $10 \mathrm{~min}$; (ii) 40 cycles of $30 \mathrm{~s}$ denaturation at $95^{\circ} \mathrm{C}, 1 \mathrm{~min}$ annealing at $55^{\circ} \mathrm{C}$ and $30 \mathrm{~s}$ extension at $72^{\circ} \mathrm{C}$ (amplification data collected at the end of each extension step); and (iii) dissociation curve consisting of 1 min incubation at $95^{\circ} \mathrm{C}, 30 \mathrm{~s}$ incubation at $55^{\circ} \mathrm{C}$, a ramp up to $95^{\circ} \mathrm{C}$. Two biological replicates, resulting from two different RNA extractions, RT and qRT-PCR reactions, were used for quantification analysis and three technical replicates were analyzed for each biological replicate.
Raw $C_{t}$ values were transformed to relative quantities using the delta- $C_{t}$ formula $Q=E^{\Delta \mathrm{Ct}}$, where $\mathrm{E}$ is the efficiency of the primer pair used in the amplification of a particular gene and $\Delta \mathrm{C}_{\mathrm{t}}$ is the difference between the sample with the lowest $C_{t}$ (highest expression) from the data set and the $C_{t}$ value of the sample in question.

The expression stability of chosen candidate reference genes (Results) was evaluated by the software program NormFinder (a Microsoft Excel Add-in available on the Internet) according to the author's recommendations (5). The expression levels of the genes of interest were compared both on three individual plants for each experimental group (H, R, and D) and by considering the average of the three plants for each group. The relative expression levels of the genes of interest were referred to that of a calibrator (the experimental unit with the lowest expression) set to one.

Standard deviations and standard error values on normalized expression levels were computed according to the geNorm user manual (available online at the geNorm website). Pairwise comparisons between the means of the three groups (H, D, and $\mathrm{R}$ ) were analyzed using the Tukey's test. The mean square error was computed as mean of the variances of the three groups. Different letters denote significant differences at $P \leq 0.01$.

\section{RESULTS}

Phytoplasma detection. Group-specific primers for AP amplified a PCR fragment of the expected size (1,050 bp) from all the leaves of D apple trees, but never from those of $\mathrm{H}$ or R plants (data not shown).

TEM. On the basis of TEM observations, the leaf tissues from $\mathrm{H}$ plants were well preserved and without ultrastructural modifications. Phytoplasmas were not detected in the sieve tubes of these plants, and callose was not present in sieve plate pores (Fig. 1A, SP). Ribosomes associated with the endoplasmic reticulum were visible (Fig. 1A, ER). The phloem-protein was uniformly dispersed into the lumen of most SE (Fig. 1B, Pp).

Phytoplasmas were instead observed in the lumen of the SE in D leaves (Fig. 1C, Phy), although the pathogen was difficult to detect because many sieve tubes were collapsed (Fig. 1C), necrotized (Fig. 1D, Cyt), or filled with starch (Fig. 1D, S), often showing, moreover, plasmolysis and cytoplasm condensation (Fig. 1E, Cyt). In the leaves of R plants, on the contrary, phytoplasmas were not detected but callose depositions were observed in their sieve tubes, particularly occluding sieve pores (Fig. 1F, G, and $\mathrm{H}, \mathrm{C}$ ). Moreover, in the mature phloem elements of $\mathrm{R}$ plants, accumulation of phloem-protein aggregates was observed, forming phloem-protein plugs and filling the cell lumen (Fig. 1F, G, and $\mathrm{H}, \mathrm{Pp}$ ).

Calcium cytolocalization and quantification. The major sites of calcium localization were the same in H, D, and R plants, namely the xylem, the secondary thickenings of the tracheid walls, and the phloem, where the main site of KPA precipitates was the plasmalemma (Fig. 2A, B, C, D, arrows). In the phloem of $\mathrm{R}$ trees, however, calcium precipitates were also associated to callose thickenings in the proximity of the cell walls and on the sieve plates (Fig. 2E and F, arrows; Pp, phloem-protein). Consistently, ICP-MS analysis showed that extractable cytosolic $\mathrm{Ca}^{2+}$ was significantly higher in $\mathrm{R}$ leaves than in D or H ones (Fig. 3).

Expression analysis of cDNAs coding for callose synthases and phloem proteins. The identification of cDNAs from genes coding for callose synthases and phloem-proteins was based on a cross search in the public databases GDR (Genome Database for Rosaceae) and TIGR apple gene index (MdGI version 1.0). Twelve sequences retrieved from the two databases referred to distinct genes and were considered suitable for cloning and expression analysis; seven of them coded for callose synthases (arbitrarily designated MDCALS1/7), four for phloem lectins (phloem protein 2) (MDPP2-1/4) and one for a protein containing 

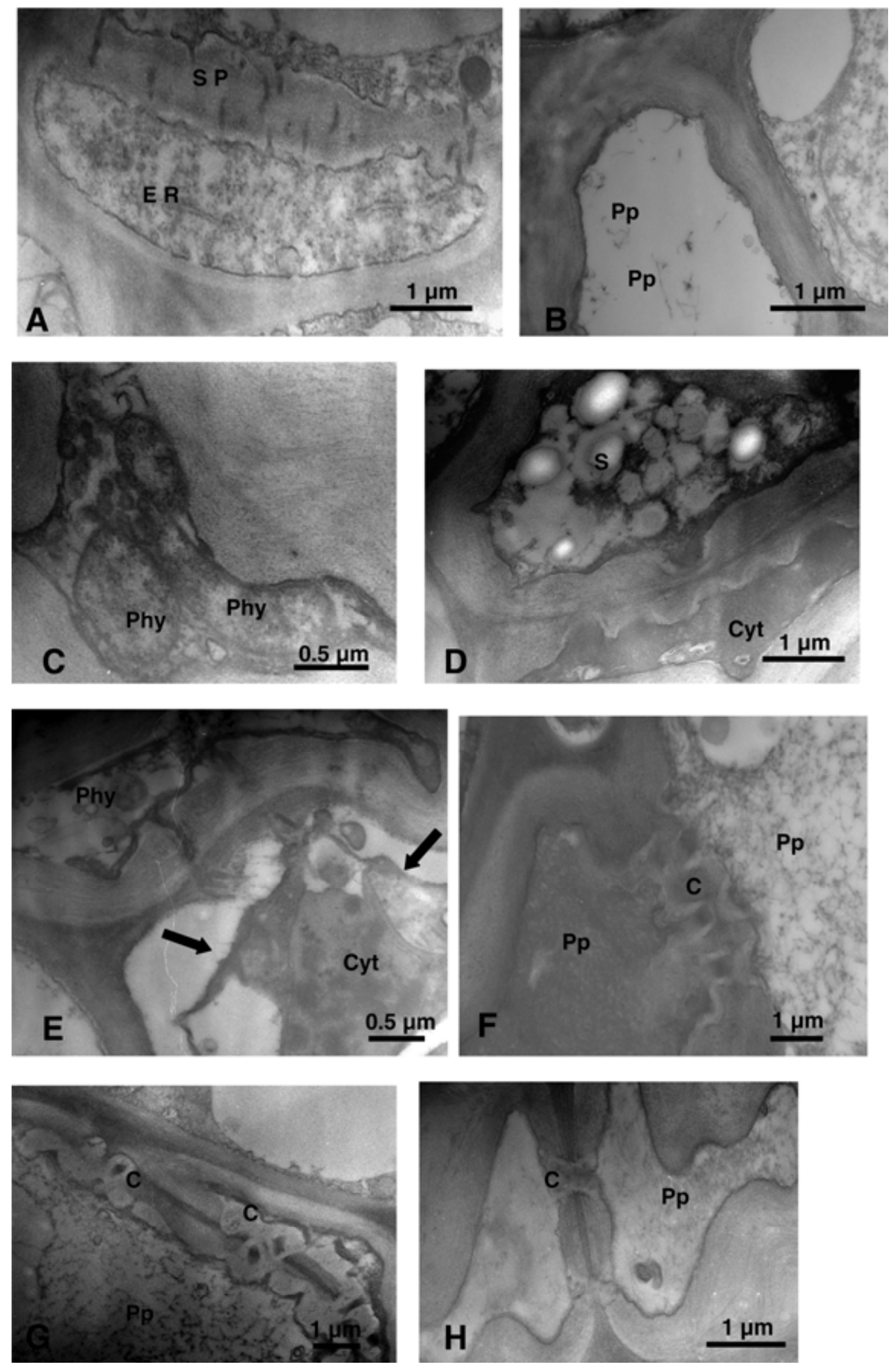

Fig. 1. A and B, Micrographs of leaf tissues from healthy apple plants. In the sieve plate pores (SP) callose is not present and ribosomes associated to the endoplasmic reticulum (ER) are visible. B, Dispersed P-protein (Pp) filaments are evident into the lumen of the sieve element. C, D, and E, Micrographs of phloem cells of leaf tissues from diseased apple trees. Phytoplasmas are visible in the lumen of sieve elements (C, E, Phy), The sieve tubes show highly condensed, dark cytoplasm (D, E, Cyt) and plasmalemma detachment from the cell wall (E, arrows). D, Cell lumen is completely filled with starch (S). F, G, and $\mathbf{H}$, Phloem cells of leaf tissue from recovered apple trees. Accumulations of P-proteins (Pp) filling the cell lumen, and callose (C) deposits in the mature phloem elements can be observed. 

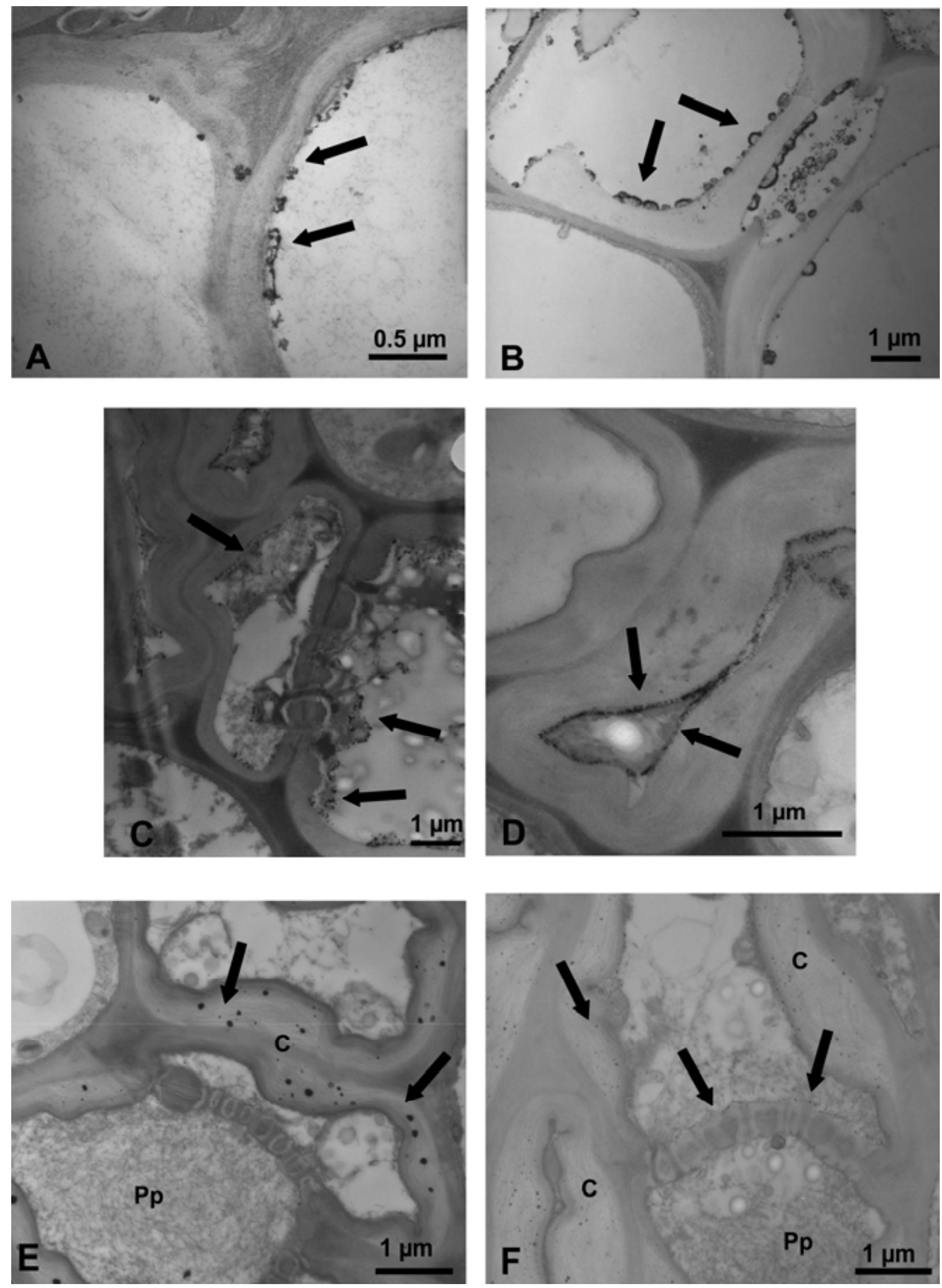

Fig. 2. Micrographs of apple leaf tissues treated with potassium pyroantimonate (KPA) for the localization of $\mathrm{Ca}^{2+}$ ions. A, In healthy plants, the calcium signal (arrows) was observed on the phloem plasmalemma and $\mathbf{B}$, on the secondary thickenings of the tracheid walls. C and D, Calcium-pyroantimonate electron-dense precipitates (arrows) observed in the phloem of diseased apple trees. $\mathbf{E}$ and $\mathbf{F}$, In recovered apple plants calcium signal is also associated to callose thickenings in the proximity of the cell walls and on the sieve plates (arrows). P-protein (Pp) plugs are accumulated in the sieve tube lumen. 
a single C2 domain (MDERG1), which was included in the present study because of its reported critical role in plant defense signaling (26). Only 9 out of the 12 primer pairs used in RT-PCR analysis amplified single and specific products of the expected size, whereas no PCR outputs were obtained for MDCALS6, MDCALS7, and MDPP2-4. Further attempts to amplify different regions of these three genes using different combinations of primer pairs were unsuccessful as well, most probably because they either are not expressed in mature leaves or are not induced by the phytoplasma infection. Thus, the RT-PCR products relative to nine genes, four coding for phloem-proteins (MDPP2-1/3 and $M D E R G 1)$ and five coding for callose synthases (MDCALS1/5), were cloned and sequenced. Their characteristics, as well as the accession numbers assigned upon deposition in the DDBJ/ EMBL/GenBank nucleotide sequence databases, are reported in Table 1.

Expression analysis by qRT-PCR was performed in triplicate for each of 36 cDNA pools (two biological replicates of three plants for each of $\mathrm{D}, \mathrm{H}$, and $\mathrm{R}$ trees for 2 years), along with no template and RT-minus controls.

To identify the most suitable reference genes for our qRT-PCR analysis, four candidates previously employed for data normalization in apple were initially selected: a gene coding for a translation elongation factor (TEF-1 $\alpha$; GenBank accession no. U80268) (6), an actin gene (GenBank accession no. CN927806), a glyceraldehyde 3-phosphate dehydrogenase gene (GAPDH;

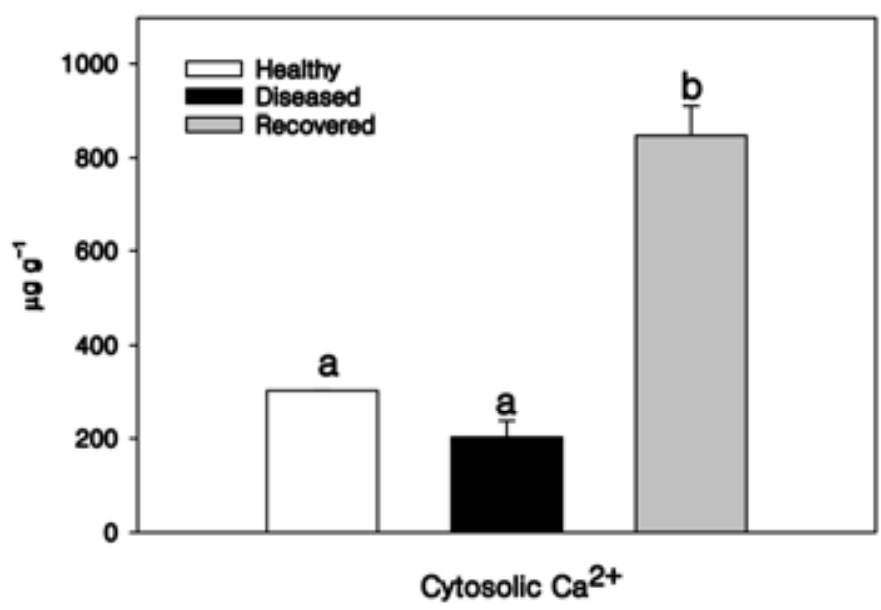

Fig. 3. Content of $\mathrm{Ca}^{2+}$ in the cytosolic fraction extracted from leaf midribs of healthy, diseased and recovered apple plants. Recovered material contained significantly higher extractable calcium than healthy and diseased ones. The error bars represent the standard error. Statistical significance of the differences was evaluated by oneway ANOVA followed by the Tukey test. Different letters denote significant differences at $P \leq 0.05$.
GenBank accession no. CN929227), and a gene of unknown function, which had previously been chosen as a reference gene on the basis of its low variability in microarray experiments (GenBank accession no. CN908822) (24). Expression stability analysis of the above genes (Materials and Methods) showed that, for the leaf sample sets collected in both 2007 and 2008, TEF-1 $\alpha$ was the most stable gene, followed by GAPDH, actin and by the gene of unknown function (data not shown). However, the combined stability of two reference genes taken together, namely TEF- $1 \alpha$ and GAPDH, was found to be significantly higher than that of the most stable reference gene, i.e., TEF- $1 \alpha$, taken alone, indicating a more reliable normalization in the former case. Therefore, the expression data of the nine genes of interest were normalized using the geometric average of the two reference genes TEF- $1 \alpha$ and GAPDH.

The 11 primer pairs used to amplify the nine genes of interest and the two reference genes generated single amplicons of the expected size from the various cDNA pools, as evidenced by the presence of single bands in agarose gel electrophoresis and of single-peak melting curves of the PCR products obtained after 40 amplification cycles (data not shown). The sequencing of the 11 amplification products represented a further and more stringent verification of the PCR specificity. In fact all the sequences of the PCR products matched those of their target cDNAs.

The expression levels of the nine genes of interest considering the mean values of three plants for each experimental group $(\mathrm{H}$, D, and R) in 2007 and 2008 are reported in Figures 4 and 5. Among the genes encoding phloem lectins (phloem protein 2), the relative transcription levels of $M D P P 2-1$ and $M D P P 2-3$ were slightly higher, about twice on average, in $\mathrm{H}$ and $\mathrm{R}$ plants than in diseased plants in both years (Fig. 4). Instead, in both years, $M D P P 2-2$ was strongly up-regulated only in the $\mathrm{R}$ plants, whose average level of transcription was approximately six times higher in 2007 and four times higher in 2008 than in $\mathrm{H}$ and D plants (Fig. 4). In $\mathrm{R}$ apple trees, the expression of MDERG1 was also up-regulated, although, in both years, its average transcription level was only twice those of H or D plants (Fig. 4).

As for the expression of the five genes encoding callose synthase, MDCALS1 and MDCALS5 were the least influenced by the sanitary status of the plants or by the year of sampling, although they tended to be up-regulated in R trees (Fig. 5). The transcription level of $M D C A L S 2$ was slightly lower in the D plants, being its average expression level about a half and twothirds, respectively, compared with $\mathrm{H}$ and $\mathrm{R}$ ones (Fig. 5). Comparatively speaking, the relative transcript abundance of $M D C A L S 3$ was very low in $\mathrm{D}$ plants, intermediate in $\mathrm{H}$ ones and very high in $\mathrm{R}$ trees, in which the expression level was, on average, five to six times higher than in D plants (Fig. 5). Finally, in both years a significant up-regulation of MDCALS4 was detected in the $\mathrm{R}$ plants in comparison to $\mathrm{H}$ and $\mathrm{D}$ ones, with an average fourfold higher transcription (Fig. 5).

TABLE 1. Characteristics of apple cDNAs coding for phloem proteins and callose synthases and homology of their deduced amino acid sequences with those of putative orthologous genes of Arabidopsis

\begin{tabular}{|c|c|c|c|c|c|c|c|c|c|c|c|}
\hline \multirow[b]{2}{*}{ Clone/gene } & \multirow{2}{*}{$\begin{array}{c}\text { Accession } \\
\text { number }\end{array}$} & \multirow{2}{*}{$\begin{array}{l}\text { Length } \\
\text { (nt) }\end{array}$} & \multicolumn{2}{|c|}{$\begin{array}{l}\text { Untranslated } \\
\text { regions }\end{array}$} & \multirow{2}{*}{$\begin{array}{l}\text { ORF } \\
\text { (nt) }\end{array}$} & \multirow[b]{2}{*}{ aa } & \multirow{2}{*}{$\begin{array}{c}\text { Protein } \\
\mathrm{kDa}\end{array}$} & \multirow[b]{2}{*}{$\mathrm{pI}$} & \multirow{2}{*}{$\begin{array}{l}\text { Putative orthologous } \\
\text { Arabidopsis gene }\end{array}$} & \multirow{2}{*}{$\begin{array}{l}\text { UniProt } \\
\text { accession } \\
\text { number }\end{array}$} & \multirow{2}{*}{$\begin{array}{l}\text { Protein } \\
\text { identity } \\
(\%)\end{array}$} \\
\hline & & & $5^{\prime}(\mathrm{nt})$ & $3^{\prime}(\mathrm{nt})$ & & & & & & & \\
\hline 1) MDPP2-1 & FN395067 & 741 & 60 & 39 & 642 & 214 & 24.64 & 9.07 & AtPP2-A1 (At4g19840) & O81865 & 38 \\
\hline 3) MDPP2-3 & FN395069 & 589 & 17 & 41 & 531 & 177 & 20.17 & 8.86 & AtPP2-A9 (At1g31200) & Q9SA16 & 43 \\
\hline 1) MDERG1 & FN395070 & 576 & 8 & 100 & 468 & 156 & 17.47 & 5.71 & C2 protein (At3g55470) & Q9M2T2 & 54 \\
\hline 4) MDCALS4 & FN395074 & 1,021 & - & 337 & 684 & 228 & & & AtCALS12 (At4g03550) & Q9ZT82 & 71 \\
\hline \multirow[t]{2}{*}{ 5) MDCALS5 } & FN395075 & 1,416 & - & - & 1,416 & 472 & & & AtCALS1 (At1g05570) & Q9AUE0 & 75 \\
\hline & & & & & & & & & AtCALS2 (At2g31960) & Q9SL03 & 75 \\
\hline
\end{tabular}




\section{DISCUSSION}

Phytoplasma diseases affecting crops, fruit trees, and grapevines are significant because of their economic consequences. As curative methods are not available against these pathogens, disease management is mainly based on controlling the insect vectors and on roguing infected crops and weeds. Although resistant cultivars are rare, plants infected by phytoplasmas can show spontaneous remission of symptoms, commonly known as recovery, which may be associated with the disappearance of the pathogen from the plant crown (38). Phytoplasma pathogenicity as well as physiological/molecular relationships with host plants is currently poorly understood, so that the molecular signals and mechanisms involved in the onset and establishment of recovery are still far from being elucidated.

Previous work of ours on a range of tree crops, such as apricot, apple and grapevine, suggested that recovery from phytoplasmaassociated diseases is linked with changes in the oxidative status of the phloem, where an accumulation of $\mathrm{H}_{2} \mathrm{O}_{2}$ invariably occurs $(33,35,36)$. At least in grapevine, recovered plants might be able to accumulate $\mathrm{H}_{2} \mathrm{O}_{2}$, a stable reactive oxygen species whose antimicrobial as well as signaling roles are well known, because in these plants the activities of two main enzymatic $\mathrm{H}_{2} \mathrm{O}_{2}$ scavengers, namely catalase and ascorbate peroxidase, are selectively and stably down-regulated (33).

There are few studies investigating phytoplasma-host interactions at the gene expression level. In grapevine, healthy, infected and recovered plants have been compared for the expression of sucrose synthase, alcohol dehydrogenase I and heat shock protein 70 genes, to determine how phytoplasmas affect sugar metabolism and stress response (20). In another study (3), extensive transcriptome analysis of two grapevine cultivars showing contrasting susceptibility, namely Chardonnay and Manzoni Bianco, revealed that phytoplasma infection altered the expression of about one hundred genes, some of which were common to both cultivars, whereas others were cultivar-specific. Repression of genes responsible for cell wall degradation and induction of genes involved in cell wall reinforcement, suggesting strengthening of physical barriers to limit phytoplasma spread, were observed in infected plants of both cultivars.

Moser et al. (32) reported on gene expression changes between healthy and AP-infected apple plants. To our knowledge, this study is the first work examining gene expression changes following recovery from phytoplasma infection in apple plants, attempting to correlate this phenomenon to cytochemical and molecular plant modifications. The association of remission of AP symptoms and phytoplasma disappearance from the plant leaves in apple observed previously $(8,38)$, was confirmed in this study. TEM investigations showed structural modifications in the phloem of recovered apple plants, such as callose deposition in the phloem bundles and accumulation of phloem-proteins, which implies a shift from the unpolymerized to the polymerized form. Because such structural transition requires an oxidative environment, favoring the cross-linking between PP1 monomers and PP2 dimers via disulphide bond formation, the accumulation of $\mathrm{H}_{2} \mathrm{O}_{2}$ occurring in the phloem tissue of recovered plants $(33,35,36)$ could be regarded as a proactive circumstance. Phloem-protein plugs may represent the sieve tube's first line of defense against the loss of assimilates, while callose deposition comes into play as a defense response in a variety of injuring circumstances (e.g., wounds).

Callose accumulation and phloem-protein deposition, detected here in recovered apple plants, have been also reported in phytoplasma-infected tobacco plants treated with elicitors (30), as well as in other pathosystems $(11,16)$, so that they can be regarded as efficient plant responses to restrict host tissue colonization by

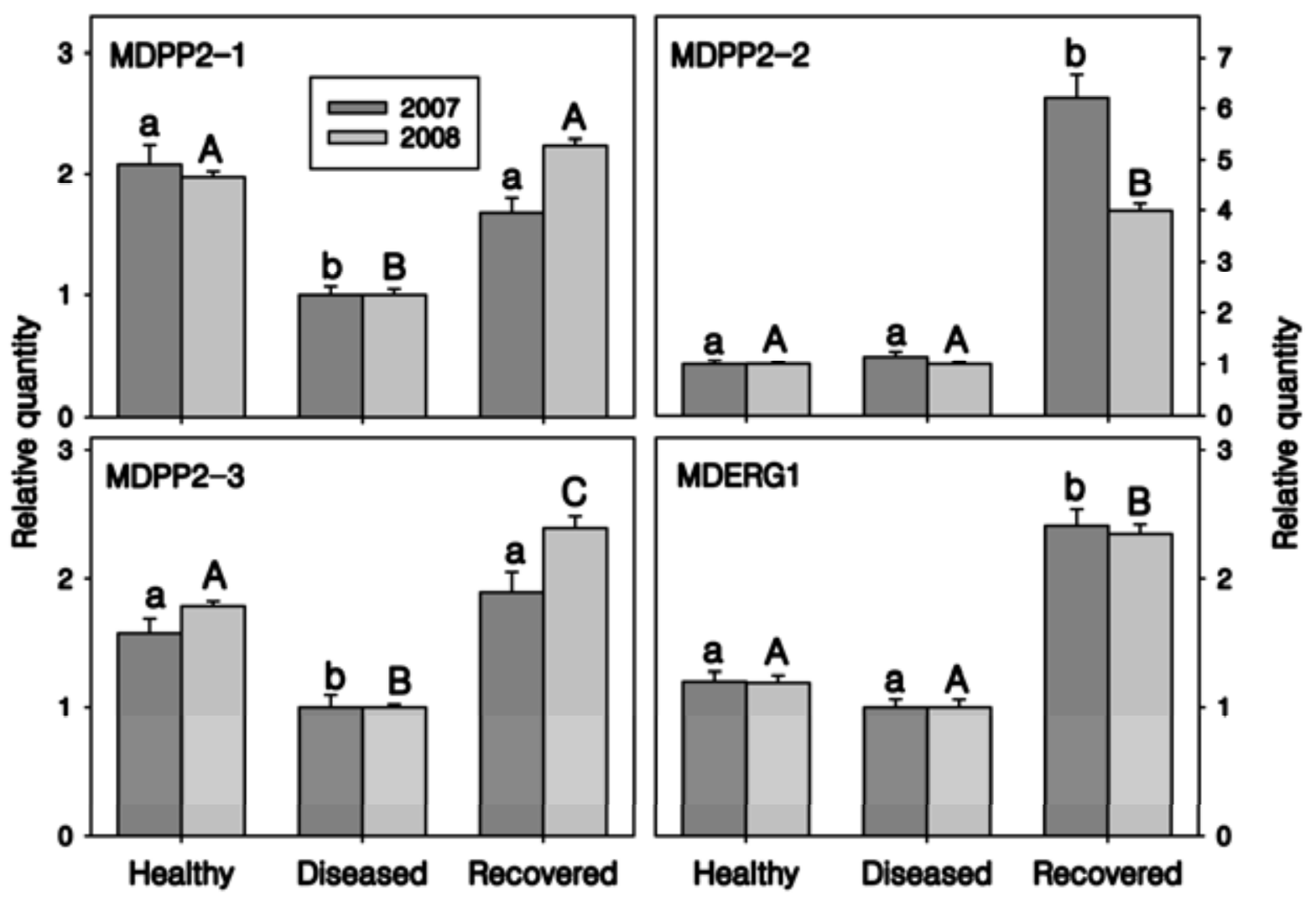

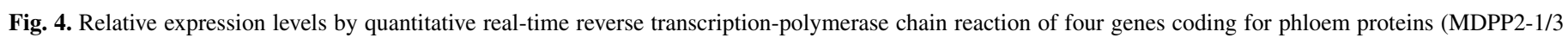

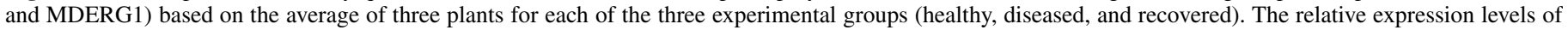

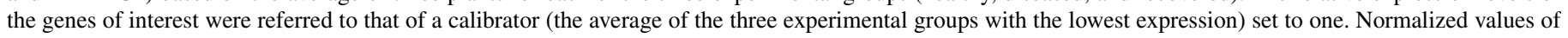
relative expressions of the four genes are given as means \pm SE. Different letters denote significant differences at $P \leq 0.01$. 
pathogens. Since it has been demonstrated that phytoplasmas are restricted to the roots in recovered apple plants (8), the above cytochemical changes might act as barriers against the pathogen spreading freely through the SE, thus preventing the recolonization of the crown. The finding of a remarkably higher $\left[\mathrm{Ca}^{2+}\right]_{\mathrm{cyt}}$ in the leaves of the recovered apple plants might reinforce the notion that callose synthesis and phloem-protein plugging are $\mathrm{Ca}^{2+}$-dependent processes $(27,28)$, regulated by $\mathrm{Ca}^{2+}$ flux into the phloem. Callose synthesis is probably the first key event among defense plant cell modifications (45), and possibly acts either by reinforcing the cell wall at the attempted site of pathogen penetration, or by providing a medium for the deposition of toxic compounds, or by impeding nutrient transfer from host to pathogen.

Callose deposition is a complex process coordinated by callose synthase (2). Most genes encoding callose synthases (CALS) identified in several plant species are members of multigene families $(12,47)$. Multiple CALS genes may have evolved in higher plants for callose synthesis at different locations and in response to different physiological and developmental signals $(19,47)$. This hypothesis received recent support from the findings of Dong et al. (9), who studied the expression pattern of the GUS reporter gene controlled by the upstream regulatory sequences of the 12 Arabidopsis callose synthase genes. Five CALS genes (AtCALS1, AtCALS5, AtCALS9, AtCALS10, and AtCALS12) were induced by the pathogen Hyaloperonospora arabidopsis, the causal agent of downy mildew in Arabidopsis, and by salicylic acid, whereas the remaining seven $C A L S$ genes were not affected. In the present study, the strong up-regulation of MDCALS3 and MDCALS4 in recovered plants appears to support the ultrastructural findings (described above) and both results point to an enhanced callose synthesis as an important component of the recovery process. It is also worth noting that MDCALS4 showed significant homology with AtCALS12, which in Arabidopsis is strongly implicated in pathogen response and wound-activated callose synthesis (22).

The up-regulation of MDERG1, observed here in recovered apple plants, might be functionally associated to changes in $\mathrm{Ca}^{2+}$

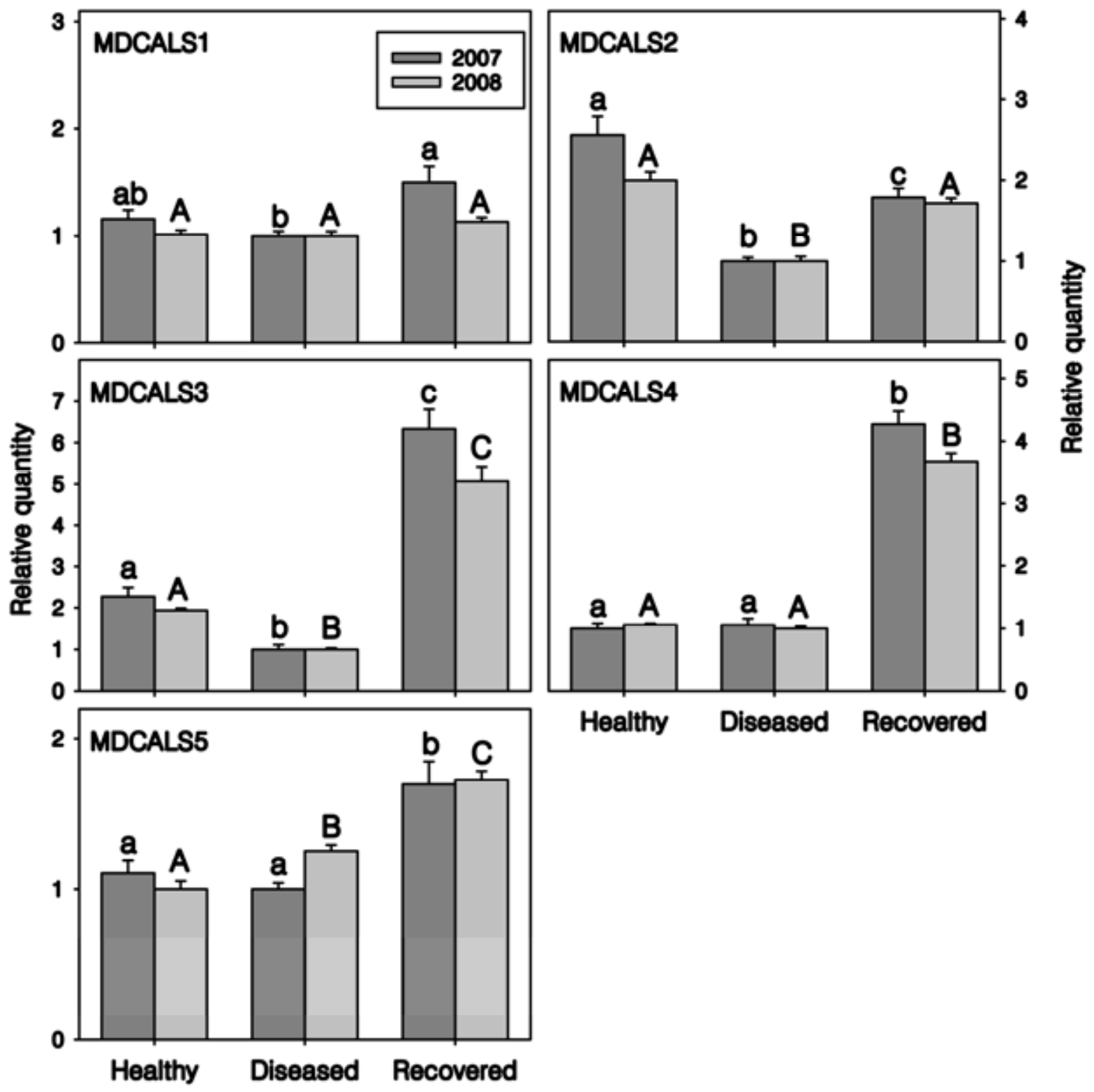

Fig. 5. Relative expression levels by quantitative real-time reverse transcription-polymerase chain reaction of five genes coding for callose synthase (MDCALS1/5) based on the average of three plants for each of the three experimental groups (healthy, diseased, and recovered). The relative expression levels of the genes of interest were referred to that of a calibrator (the average of the three experimental groups with the lowest expression) set to one. Normalized values of relative expressions of the five genes are given as means \pm SE. Different letters denote significant differences at $P \leq 0.01$. 
intracellular compartmentation. Indeed, OsERG1, the MDERG1 ortholog in rice, is significantly and rapidly induced by a fungal elicitor. The MDERG1 protein interacts with phospholipids in a $\mathrm{Ca}^{2+}$-dependent manner and it is translocated to the plasma membrane of plant cells by treatment with either a fungal elicitor or a $\mathrm{Ca}^{2+}$ ionophore (26). Orthologues of MDERG1 are also specifically activated in response to other biotrophic pathogens, as well as by abiotic stress. A cDNA sequence (HO02F02) of barley, orthologous to OsERG1, was specifically up-regulated in cells infected by Blumeria graminis f. sp. hordei (15). By using Genevestigator software (48), we found that AtC2-1 (At355470) of Arabidopsis is strongly induced by both biotic and abiotic stresses. On the whole, these findings suggest that in plant cells small C2-domain proteins, such as MDERG1, may play a functional role in defense signaling systems. It is not known whether MDERG1 activation is required to transduce the $\mathrm{Ca}^{2+}$ signals to downstream signaling pathways; however its higher expression in recovered plants deserves further investigations.

The influx of $\mathrm{Ca}^{2+}$ into $\mathrm{SE}$ promotes also a rapid and reversible dispersion of crystalloid phloem-protein to occlude sieve plate pores (27). The aggregation of phloem-proteins into the sieve tubes is among the first responses of phloem cells to $\mathrm{pH}$ modifications (16). Among different possible causes, phloem-protein aggregation may be related to pathogen attack (27).

The data presented here show that in the leaf phloem of recovered apple trees an accumulation of polymerized phloemproteins do occur, which is consistent with a four to six times higher induction of $M D P P 2-2$, coding for a phloem-specific lectin (phloem protein 2) in the same plants in respect to their healthy or diseased counterparts. It has recently been reported that a gene coding for a phloem-specific lectin was strongly induced in Citrus following infection with the phloem-limited bacterial pathogen 'Candidatus Liberibacter asiaticus' (4). As discussed previously, accumulation of phloem-specific proteins at the sieve plates is generally considered to cause blockage of the translocation stream (43). Since transcripts of the citrus phloem lectin gene were detected neither 5 to 9 weeks after inoculation nor in infected but symptomless plants, the induction of this gene appears to be directly linked to symptom development and may be an attempt of the host plant to seal the sieve tubes as a barrier against an increasing bacterial population. Besides defensive plugging and sieve cell differentiation, recent studies have demonstrated that phloem lectin-like proteins are able to interact with RNA molecules, are involved in the long-distance trafficking of macromolecules and may thus play a role in long-distance signaling in response to infection by plant pathogens $(16,17,39)$. Furthermore, phloem-proteins might be involved in defense reaction by participating in the trafficking, synthesis, modulation or amplification of systemic signals.

In conclusion, an integrated approach combining ultrastructural, cytochemical, and gene expression analyses suggests here that callose synthesis/deposition and phloem-protein aggregation in the phloem might play important roles in the recovery of apple trees from phytoplasma disease. Both the above defense reactions might become activated following an inward flux of $\mathrm{Ca}^{2+}$, acting as a signaling intermediate, across the phloem plasma membrane.

\section{ACKNOWLEDGMENTS}

This research was supported by ERSA Friuli Venezia Giulia (Italy), Project "Studio volto al recupero e alla valorizzazione di varietà di melo autoctone del Friuli Venezia Giulia".

\section{LITERATURE CITED}

1. Ahrens, U., and Seemüller, E. 1992. Detection of DNA of plant pathogenic mycoplasmalike organisms by a polymerase chain reaction that amplifies a sequence of the $16 \mathrm{~S}$ rRNA gene. Phytopathology 82:828832.
2. Aidemark, M., Andersson, C.-J., Rasmusson, A. G., and Widell, S. 2009. Regulation of callose synthase activity in situ in alamethicin-permeabilized Arabidopsis and tobacco suspension cells. BMC Plant Biol. 9:27-39.

3. Albertazzi, G., Milc, J., Caffagni, A., Francia, E., Roncaglia, E., Ferrari, F., Tagliafico, E., Stefani, E., and Secchioni, N. 2009. Gene expression in grapevine cultivars in response to Bois Noir phytoplasma infection. Plant Sci. 176:792-804.

4. Albrecht, U., and Bowman, K. D. 2008. Gene expression in Citrus sinensis (L.) Osbeck following infection with the bacterial pathogen Candidatus Liberibacter asiaticus causing Huanglongbing in Florida. Plant Sci. 175:291-306.

5. Andersen, C. L., Jensen, J. L., and Orntoft, T. F. 2004. Normalization of real-time quantitative reverse transcription-PCR data: A model-based variance estimation approach to identify genes suited for normalization, applied to bladder and colon cancer data sets. Cancer Res. 64:5245-5250.

6. Bonasera, J. M., Kimand, J. F., and Beer, S. V. 2006. PR genes of apple: Identification and expression in response to elicitors and inoculation with Erwinia amylovora. BMC Plant Biol. 6:23.

7. Carginale, V., Capasso, M. G., Ionata, E., La Cara, F., Pastore, M., Bertaccini, A., and Capasso, A. 2004. Identification of genes expressed in response to phytoplasma infection in leaves of Prunus armeniaca by messenger RNA different display. Gene 332:29-34.

8. Carraro, L., Ermacora, P., Loi, N., and Osler, R. 2004. The recovery phenomenon in apple proliferation infected apple trees. J. Plant Pathol. 86:141-146

9. Dong, X., Hong, Z., Chatterjee, J., Kim, S., and Verma, D. P. S. 2008. Expression of callose synthase genes and its connection with Npr1 signaling pathway during pathogen infection. Planta 229:87-98.

10. Donofrio, N. M., and Delaney, T. P. 2001. Abnormal callose response phenotype and hypersusceptibility to Peronospora parasitica in defensecompromised Arabidopsis nim1-1 and salicylate hydroxylase plants. Mol. Plant-Microbe Interact. 14:439-50.

11. Elad, Y., and Evensen, K. 1995. Physiological aspects of resistance to Botrytis cinerea. Phytopathology 85:637-643.

12. Farrokhi, N., Burton, R. A., Brownfield, L., Hrmova, M., Wilson S. M., Basic, A., and Fincher, G. B. 2006. Plant cell wall biosynthesis: Genetic, biochemical and functional genomics approaches to the identification of key genes. Plant Biotechnol. J. 4:145-167.

13. Furch, A. C. U., Hafke, J. B., Schulz, A., and Van Bel, A. J. E. 2007. Ca ${ }^{2+}$ mediated remote control of reversible sieve tube occlusion in Vicia faba. J. Exp. Bot. 58:2827-2838.

14. Gasic, K., Hernandez, A., and Korban, S. S. 2004. RNA extraction from different apple tissues rich in polyphenols and polysaccharides for cDNA library construction. Plant Mol. Biol. Rep. 22:437a-437g.

15. Gjetting, T., Hagedorn, P. H., Schweizer, P., Thordal-Christensen, H., Carver, T. L. W., and Lyngkjær, M. F. 2007. Single-cell transcript profiling of barley attacked by the powdery mildew fungus. Mol. PlantMicrobe Interact. 20:235-246.

16. Goleki, B., Schulz, A., and Thompson, G. A. 1999. Translocation of structural P-proteins in the phloem. Plant Cell 11:127-140.

17. Gomez, G., and Pallas, V. 2001. Identification of an in vitro ribonucleoprotein complex between a viroid RNA and a phloem protein from cucumber plants. Mol. Plant-Microbe Interact. 14:910-913.

18. Hayat, M. A. 1993. Stains and Cytochemical Methods. Plenum Press, New York.

19. Hong, Z., Delauney, A. J., and Verma, D. P. S. 2001. A cell plate-specific callose synthase and its interaction with phragmoplastin. Plant Cell 13:755-768.

20. Hren, M., Ravnikar, M., Brzin, J., Ermacora, P., Carraro, L., Bianco, P. A., Casati, P., Borgo, M., Angelici, M., Rotter, A., and Gruden, K. 2009. Induced expression of sucrose synthase and alcohol dehydrogenase I genes in phytoplasma-infected grapevine plants grown in the field. Plant Pathol. 58:170-180.

21. IRPCM. 2004. International Research Programme on Comparative Mycoplasmology, IRPCM, Phytoplasma/Spiroplasma Working TeamPhytoplasma Taxonomy Group. 'Candidatus Phytoplasma', a taxon for the wall-less, non helical prokaryotes that colonise plant phloem and insects. Int. J. Syst. Evol. Microbiol. 54:1243-1255.

22. Jacobs, A. K., Lipka, V., Burton, R. A., Panstruga, R., Strizhov, N., Schulze-Lefert, P., Fincher, G. B. 2003. An Arabidopsis callose synthase, GSL5, is required for wound and papillary callose formation. Plant Cell 15:2503-2513

23. Jagoueix-Eveillard, S., Tarendeau, F., Guolter, K., Danet, J.-L., Bové, J. M., and Garnier, M. 2001. Catharanthus roseus genes regulated differentially by Mollicute infections. Mol. Plant-Microbe Interact. 14:225-233.

24. Janssen, B. J., Thodey, K., Schaffer, R. J., Alba, R., Balakrishnan, L., Bishop, R., Bowen, H. J., Crowhurst, R. N., Gleave, A. P., Ledger, S., 
McArtney, S., Pichler, F. B., Snowden, K. C., and Ward, S. 2008. Global gene expression analysis of apple fruit development from the floral bud to ripe fruit. BMC Plant Biol. 8:16-44.

25. Jung, S., Staton, M., Lee, T., Blenda, A., Svancara, R., Abbott, A., and Main, D. 2008. GDR (Genome Database for Rosaceae): Integrated webdatabase for Rosaceae genomics and genetics data. Nucleic Acids Res. 37:1-7.

26. Kim, C. Y., Koo, Y. D., Jin, J. B., Moon, B. C., Kang, C. H., Kim, S. T., Park, B. O., Lee, S. Y., Kim, M. L., Hwang, I., Kang, K. Y., Bahk, J. D., Lee, S. Y., and Cho, M. J. 2003. Rice C2-domain proteins are induced and translocated to the plasma membrane in response to a fungal elicitor. Biochemistry 42:11625-11633.

27. Knoblauch, M., Peters, W. S., Ehlers, K., and Van Bel, A. J. E. 2001. Reversible calcium-regulated stopcocks in legume sieve tubes. Plant Cell 13:1221-1230.

28. Köhle, H., Jeblick, W., Poten, F., Blascheck, W., and Kauss, H. 1985. Chitosan-elicited callose synthesis in soybean cells as a $\mathrm{Ca}^{2+}$-dependent process. Plant Physiol. 77:544-551.

29. Lecourieux, D., Ranjeva, R., and Pugin, A. 2006. Calcium in plant defense-signaling pathways. New Phytol. 171:249-269.

30. Lherminier, J., Benhamou, N., Larrue, J., Milet, M. L., Boudon-Padieau, E., Nicole, M., and Blein, J. P. 2003. Cytological characterization of elicitin induced protection in tobacco plants infected by Phytophthora parasitica or phytoplasma. Phytopathology 93:1308-1319.

31. Lorenz, K.-H., Schneider, B., Ahrens, U., and Seemüller, E. 1995. Detection of the apple proliferation and pear decline phytoplasmas by PCR amplification of ribosomal and nonribosomal DNA. Phytopathology 85:771-776.

32. Moser, M., Sprenger, C., Bisognin, C., Velasco, R., and Jaraush, W. 2007. Gene expression study in different ' $C a$. Phytoplasma mali'-infected micropropagated Malus genotypes. Bull. Insectol. 60:207-208.

33. Musetti, R., Marabottini, R., Badiani, M., Martini, M., Sanità di Toppi, L., Borselli, S., Borgo, M., and Osler, R. 2007. On the role of $\mathrm{H}_{2} \mathrm{O}_{2}$ in the recovery of grapevine (Vitis vinifera cv. Prosecco) from Flavescence Dorée disease. Funct. Plant Biol. 34:750-758.

34. Musetti, R., Martini, M., Ermacora, P., Ferrini, F., Loi, N., and Osler, R. 2008. "Ca. Phytoplasma mali" causing apple proliferation. Pages 35-58 in: Characterization and Identification of Phytoplasmas. N. A. Harrison, G. P. Rao, and C. Marcone, eds. Studium Press LLC, Texas.

35. Musetti, R., Sanità di Toppi, L., Ermacora, P., and Favali, M. A. 2004. Recovery in apple trees infected with the apple proliferation phytoplasma:
An ultrastructural and biochemical study. Phytopathology 94:203-208.

36. Musetti, R., Sanità di Toppi, L., Martini, M., Ferrini, F., Loschi, A.,. Favali, M. A., and Osler, R. 2005. Hydrogen peroxide localisation and antioxidant status in the recovery of apricot plants from European stone fruit yellows. Eur. J. Plant Pathol. 112:53-61.

37. Nicolaisen, M., and Horvath, D. P. 2008. A branch-inducing phytoplasma in Euphorbia pulcherrima is associated with changes in expression of host genes. J. Phytopathol. 156:403-407.

38. Osler, R., Loi, N., Carraro, L., Ermacora, P., and Refatti, E. 2000. Recovery in plants affected by phytoplasmas. Pages 589-592 in: Proc. 5th Congr. Eur. Found. for Plant Pathol. Società Italiana di Patologia Vegetale, ed. Taormina, Italy.

39. Owens, R. A., Blackburn, M., and Ding, B. 2001. Possible involvement of the phloem lectin in long-distance viroid movement. Mol. PlantMicrobe Interact. 14:905-909.

40. Quackenbush, J., Cho, J., Lee, D., Liang, F., Holt, I., Karamycheva, S., Parvizi, V., Pertea, G., Sultana, R., and White, J. 2001. The TIGR Gene Indices: Analysis of gene transcript sequences in higly sampled eukaryotic species. Nucleic Acids Res. 29:159-164.

41. Radonic, A., Thulke, S., Mackay, I. M., Landt, O., Siegert, W., and Nitsche, A. 2004. Guideline to reference gene selection for quantitative real-time PCR. Biochem. Res. Commun. 313:856-862.

42. Read, S. M., and Northcote, D. H. 1983. Chemical and immunological similarities between the phloem proteins of three genera of the Cucurbitaceae. Planta 158:119-127.

43. Schneider, H. 1968. Anatomy of greening-diseased sweet orange shoots. Phytopathology 58:1155-1160.

44. Seemüller, E. 1988. Colonization pattern of mycoplasmalike organisms in trees affected by apple proliferation and pear decline. Pages 179-192 in: Tree Mycoplasmas and Mycoplasma Diseases. C. Hiruki, ed. The University of Alberta Press, Edmonton, Alberta, Canada.

45. Skou, J. P., Jorgensen, J. H., and Lilholt, U. 1984. Comparative studies on callose formation in powdery mildew compatible and incompatible barley Hordeum vulgare. Phytopathol. Z. 109:147-168.

46. Van Bel, A. J. E. 2003. The phloem, a miracle of ingenuity. Plant Cell Environ. 26:125-150.

47. Verma, D. P. S., and Hong, Z. 2001. Plant callose synthase complexes. Plant Mol. Biol. 47:693-701.

48. Zimmermann, P., Hirsch-Hoffmann, M., Hennig, L., and Gruissem, W. 2004. GENEVESTIGATOR. Arabidopsis microarray database and analysis toolbox. Plant Physiol. 136:2621-2632. 